\title{
Toxicity of cryoprotectants on Prochilodus lineatus (Valenciennes, 1837) (curimba) embryos in an experimental incubator (Characiformes: Prochilodontidae)
}

\author{
Daniella A. J. Paula1, Mônica R. F. Machado², Luis D. S. Murgas³, Denílson Rabelo ${ }^{4}$, \\ Márcio G. Zangerônimo ${ }^{3}$, Rafael V. R. Neto ${ }^{5}$, Estefânia S. Andrade ${ }^{3}$ \\ and Eliane A. Andrade ${ }^{3}$
}

This paper investigated the effect of cryoprotectant substances on Prochilodus lineatus embryos in an experimental incubator. The prospective study applied combinations of polyvinyl alcohol, hydroxyethyl cellulose, gelatin and fetal bovine serum with dimethyl sulfoxide and ethylene glycol in a new experimental incubator. The morphology of embryos, larval viability and the efficiency of experimental incubators in maintaining the quality of embryos were evaluated. This study demonstrates the efficient association between hydroxyethylcellulose and dimethyl sulfoxide as greater viability $(\mathrm{p}<0.05)$ was found for embryos $(72.9 \pm 23.9 \%)$. It should also be noted the permeation of cryoprotectants in embryos through the changes found in chorion diameter, embryo diameter and embryo volume comparing the treatments versus control group (water) $(\mathrm{p}<0.05)$, this results can help in future cryopreservation protocols. Although the temperature and oxygenation differed between the usual and experimental incubators $(\mathrm{p}<0.05)$, the results showed a high fertilization rate $(79.6 \pm 13.2 \%)$ for experimental incubators $(\mathrm{p}<0.05)$ which is sufficient for the maintenance of embryos in a cryoprotective environment and effectively allows experimentation for long periods with cryoprotectant substances. Cryopreservation of fish embryos has not been accomplished yet and new approaches are required for understanding the permeability of teleost embryos, especially in Brazilian native species.

Este trabalho avaliou o efeito de substâncias crioprotetoras sobre embriões de Prochilodus lineatus em uma incubadora experimental. $\mathrm{O}$ estudo aplicou combinações de álcool polivinílico, hidroxietilcelulose, gelatina e soro fetal bovino com dimetilosulfóxido e etilenoglicol em uma nova incubadora experimental. Foram avaliadas a morfologia dos embriões, a viabilidade larval e a eficiência das incubadoras experimentais na manutenção da qualidade dos embriões. Este estudo demonstra a associação eficiente entre hidroxietilcelulose e dimetilsulfóxido pela maior viabilidade $(\mathrm{p}<0,05)$ encontrada para os embriões $(72,9 \pm 23,9 \%)$. Deve-se notar também a permeação dos crioprotetores nos embriões através das alterações encontradas no diâmetro córion, diâmetro do embrião e no volume do embrião comparando os tratamentos ao grupo controle (água) $(\mathrm{p}<0,05)$, estes resultados podem ajudar em futuros protocolos de criopreservação. Embora a temperatura e a oxigenação diferiram entre as incubadoras comuns e as experimentais $(p<0,05)$, os resultados mostraram elevada taxa de fertilização $(79,6 \pm 13,2 \%)$ para incubadoras experimentais $(p<0,05)$, o que é suficiente para a manutenção de embriões em ambiente crioprotetor e permite efetivamente a experimentação por longos períodos com substâncias crioprotetoras. A criopreservação de embriões de peixes ainda não foi realizada e novas abordagens são necessárias para a compreensão da permeabilidade dos embriões de teleósteos, especialmente em espécies nativas brasileiras.

Key words: Fertilization, Freshwater fish, Morphology, Reproduction.

\footnotetext{
${ }^{1}$ Universidade Federal de Lavras, Departamento de Zootecnia, Campus Universitário, 37200-000 Lavras, MG, Brazil. daniufla2002@ yahoo.com.br (DAJP)

${ }^{2}$ Pontifícia Universidade Católica de Goiás, Av. Universitária, 7460-5010 Goiânia, GO, Brazil. monicavet_2@hotmail.com (MRFM)

${ }^{3}$ Universidade Federal de Lavras, Departamento de Medicina Veterinária, Campus Universitário, Centro, 37200-000 Lavras, MG, Brazil. 1smurgas@ufla.br (LDSM), zangeronimo@ufla.br (MGZ), esandrade@bol.com.br (ESA), eandrade70@yahoo.com.br (EAA) ${ }^{4}$ Universidade Federal de Goiás, Instituto de Química, IQII, 74001-970 Goiânia, GO, Brazil. rabelo.denilson@gmail.com (DR) ${ }^{5}$ Universidade Estadual Paulista, Campus Experimental de Registro, Nelson Brihi Badur, 11900-000 Registro, SP, Brazil. rafaneto2003@ yahoo.com.br (RVRN)
} 


\section{Introduction}

Piracema fish comprise a significant proportion of the Brazilian fish fauna and their reproduction occurs once a year. They would not only benefit from programs to recover rivers, but also programmes for the reproduction of these species in captivity by artificial propagation and reintroduction (Murgas et al., 1997; Viveiros et al., 2010a). Cryopreservation of embryos is one alternative for the conservation of fish species as this technique allows maintenance of cells in liquid nitrogen for long periods and preserves genetic material.

The curimba (Prochilodus lineatus) is a migratory native species of South America (Viveiros et al., 2009) used in commercial polycultures and for fishing subsistence or commercialization (Maduenho \& Martinez, 2008). Furthermore, it is used as a model in research in the reproductive biotechnology of Brazilian fish (Viveiros et al., 2010b), thanks to its high prolificacy and ease of management. As a migratory species, curimba needs to swim upriver to spawn and this cycle has been drastically affected (Paula et al., 2012). Cryopreservation is a biotechnology for its conservation and a tool for assisted reproduction on a large scale.

However, this technique does not constitute an effective protocol, mainly because of the difficulties in developing substances that penetrate the chorionic sac and protect the embryo from formation of intracellular ice crystals during the procedure (Kusuda et al., 2002; Ninhaus-Silveira et al., 2009). Although Hagedorn et al., (1996) observed in images by magnetic resonance that methanol permeated the entire zebrafish embryo within 15 min and propylene glycol and dimethyl sulfoxide exhibited little or no penetration over $2.5 \mathrm{~h}$ and considered that the yolk syncytial layer may be selectively permeable to specific charges or conformations.

Various cryoprotectant solutions have been used in different protocols with different results. For zebrafish (Brachydanio rerio), 2M methanol proved to be more effective and less toxic (Zhang et al., 1993). For curimba, $1.5 \mathrm{M}$ of dimethyl sulfoxide and propylene glycol proved to be less toxic, promoting the highest percentage of survival (78.95\%) after toxicity assays, but no embryos survived after cryopreservation (Ninhaus-Silveira et al., 2009).

Sucrose and methanol were tested in cryopreservation of pacu (Piaractus mesopotamicus), solutions containing $8.5 \%, 17 \%, 25.5 \%$ and $34 \%$ of sucrose associated with $9 \%$ methanol determined a reduced level of injury on morphological structures of fish embryos, although no embryo survived after freezing (Fornari et al., 2011). The use of $10 \%$ methanol associated with $0.5 \mathrm{M}$ sucrose resulted in $49 \%$ of larvae survival, when cooling of embryos was performed after blastopore closure (Lopes et al., 2011).

Substances such as polyvinyl alcohol (Naitana et al., 1997; Wowk et al., 2000; Checura \& Seidel 2007) and fetal bovine serum (Vajta et al., 1999) have been successfully tested in freezing embryos of mice, sheep and cattle.
According Nowshari \& Brem (2000) polyvinyl alcohol appears to be a suitable replacement for biologically derived macromolecules like fetal bovine serum and eliminates the chance of contamination with infectious agents; it can be substituted for fetal bovine serum in medium for freezing mouse embryos. In addition, substances such as hydroxyethyl cellulose and gelatin have not been tested on embryos of any species, and present the characteristics of cryogels with complex structures, having porous compartments which originate from gelation of concentrated aqueous solution (Shapiro \& Shapiro, 1999).

If fish embryos have multi-compartmentalized structures the exchange of water/cryoprotectant is difficult and during their early stages they are more permeable (Martínez-Páramo et al., 2008; 2009). The exposure time to cryoprotectant on the protocols, the fresh embryos are typically exposed for only few minutes, at ambient temperature, after blastopore closure ( $8 \mathrm{~h}$ post-fertilization) and cooled (Lopes et al., 2011). New models of incubators could allow the maintenance of embryos in a cryoprotective environment, combined with a suitable environment for embryo development.

Thus the objective of the study was to investigate the effect of cryoprotectant substances on curimba embryos in an experimental incubator, allowing a longer period of exposure to the external cryoprotectants polyvinyl alcohol, hydroxyethyl cellulose, gelatin and fetal bovine serum in association with the internal cryoprotectant ethylene glycol or dimethyl sulfoxide.

\section{Material and Methods}

Animals and incubation. The experiment took place from December 2010 to February 2011 at the Estação Ambiental de Itutinga da Companhia Energética de Minas Gerais (Itutinga Environmental Station of the Companhia Energética de Minas Gerais) (EAI-CEMIG), in the city of Itutinga, Minas Gerais, Brazil. Six pairs of wild curimba (mean weight females: $1191 \pm 496 \mathrm{~g}$ and mean weight males: $675 \pm 296 \mathrm{~g}$ ), kept in inland hatcheries in the station for a maximum of three years, were used. They were ready to reproduce, and were selected by abdominal massage to check the release of sperm in males and evaluation of the urogenital papillae in females (prominent with pinkish or reddish coloration and genital orifice slightly open). During the breeding season the females have a bulging belly and are removed from water for visualization of the papillae. If the papillae are reddish in color the fish is selected for application of hormones.

The specimens were sent to masonry aquariums and received hormonal application of crude carp pituitary extract (Argent Chemical Laboratory, Redmond, WA, USA). The initial and final doses of hormone given were 0.5 and $5 \mathrm{mg} / \mathrm{kg}$ of fish and 0.4 and $4 \mathrm{mg} / \mathrm{kg}$ of fish, for females and males respectively. The application of the hormone was done intramuscularly, with a syringe of $1 \mathrm{~mL}$ and near the 
base of the dorsal fin, at intervals of $12 \mathrm{~h}$ (Murgas et al., 1997; Ninhaus-Silveira et al., 2006).

Twenty-four hours after the initial dose, the urogenital papillae were cleaned and dried with paper towels to prevent contamination and activation of gametes with water, urine or faeces. Then hand massage of the coelomic wall was performed gently in cranial-caudal orientation to promote the release of gametes (spawning $214 \pm 66.61 \mathrm{~g}$; sperm: 2.83 $\pm 1.72 \mathrm{~mL}$ ).

The fertilization of gametes was performed with the addition of water from the tank itself. The amount $6 \pm 1 \mathrm{~g}$ of embryos from each curimba couple were weighed and then taken to incubators containing the experimental treatments in section "Effect of cryoprotectant" where they remained for $8 \mathrm{~h}$.

The experimental incubators were made of polyvinyl chloride tubes (PVC) $(6 \mathrm{~cm}$ in diameter, $10 \mathrm{~cm}$ high and with $400 \mathrm{~mL}$ capacity) and these were arranged on a wooden support compatible with the pipe size. The incubators were supplied with oxygen through a tank aeration sponge, centered on the PVC pipe and connected to oxygen inhalers (Aquarium Air Pump, Power ${ }_{\mathrm{TM}}$ 100) through hoses suitable for aquariums (Fig. 1). The incubator system was a closed system without recirculation of water but with constant aeration, thus maintaining the concentration of cryoprotective agents and was compared the funnel incubator.

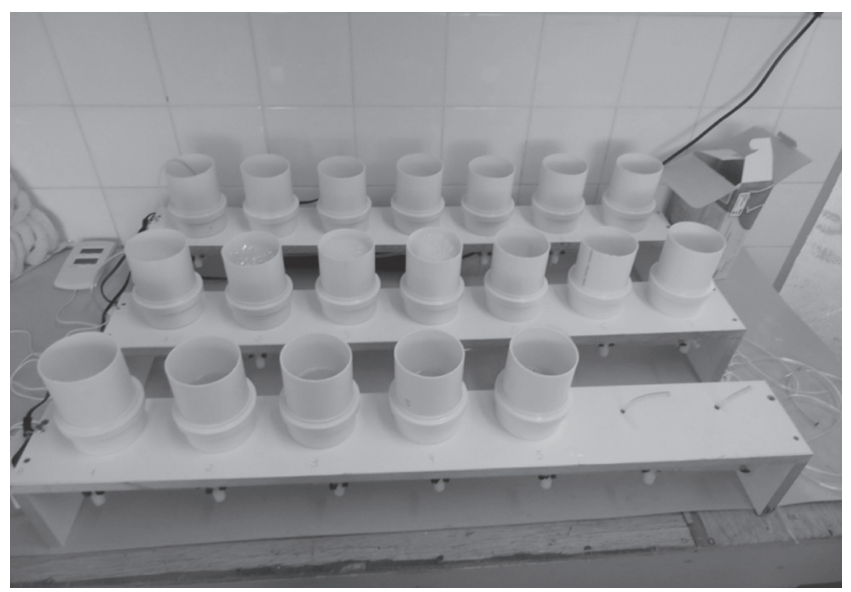

Fig 1. Representative image of the experimental incubators.

The Núcleo de Inovação Tecnológica, NINTEC/ UFLA, conducted prior searches of the national banks and international patents to validate the uniqueness of the technology entitled 'Sistema de Incubação Experimental para Embriões de Peixe' ('Experimental System for Incubation of Fish Embryos') and subsequently applied for a patent under the provisions of Law 9.279 of 14 May 1996, which describes the rights and obligations relating to industrial property, the technology attended the necessary prerequisites for patenting. The technology was deposited at INPI (National Institute of Industrial Property), on 12 July 2013, as n ${ }^{\circ}$ BR 102013017858 6, and will remain there for the requisite 18 months. A copy of the filed process was archived at NINTEC/UFLA for purposes of evidence.

The temperature and oxygen in the experimental incubators were measured every hour for $10 \mathrm{~h}$. Type funnel incubators $(200 \mathrm{~L})$ are commonly used in commercial fish farms and were also checked and used as control. They are made of glass fibre, tubular, in support tripod type, with constant circulation of water at $26.98 \pm 1.05{ }^{\circ} \mathrm{C}$ during experiment.

The fertilization rate of both types of incubator was measured approximately $8 \mathrm{~h}$ after fertilization of gametes in terms of the relationship between the number of good embryos and overall embryos counted in a sample (200 embryos), multiplied by 100 . Good embryos constituted transparent embryos with development in $90 \%$ of epibolia phase. Opaque embryos could not permit to identify their phase, consequently they were deemed dead and were not considered any further.

Subsequent to exposure time $(8 \mathrm{~h})$, the embryos were transferred to commonly used $1 \mathrm{~L}$ incubators (Felizardo et al., 2010) in a masonry tank with constant water circulation and oxygenation to complete their development. After hatching, the larvae were evaluated in a stereomicroscope, and the total number of viable larvae was counted (i.e. those which had hatched and were not deformed).

Effect of cryoprotectant. Four substances, polyvinyl alcohol (PVA), hydroxyethyl cellulose (HEC), gelatin (GEL) in concentrations of $0.5 \%$ and $1 \%$ and fetal bovine serum (BSF) in concentrations of $4 \%$ and $8 \%$ were tested and combined with dimethyl sulfoxide (DMSO) and ethylene glycol (EG), both in concentrations of 3\%. The substances tested in this study have the potential to be external cryoprotectant by its degradability and form gels. The solutions were added to a medium $(160 \mathrm{~mL})$ to develop embryos, E3, composed of $8.6 \mathrm{~g} \mathrm{NaCl}, 0.38 \mathrm{~g} \mathrm{KCl}, 1.46 \mathrm{~g}$ of $\mathrm{CaCl}_{2}$ and $2.45 \mathrm{~g} \mathrm{MgSO}_{4}$ (Di Prinzio et al., 2010; Haffter et al., 1996). An additional treatment containing only water from the recirculation system was used as control to compare the solutions that were prepared $12 \mathrm{~h}$ prior for component stabilization.

Morphometric analysis. During the eight hours while the embryos were kept in cryoprotectants images were captured of three embryos per treatment in 15, $30 \mathrm{~min}$ and $60 \mathrm{~min}$. These images were evaluated with the public domain software ImageJ (Schneider et al., 2012). The medium chorion diameter (CD), the medium embryo diameter (ED) and the medium volume in $\mu \mathrm{m}$ were used to measure morphology. The axes were used to determine the volume of all embryos with a prolate spheroid formula $\left(\mathrm{V}=4 / 3 \pi \mathrm{ab}^{2}\right)$, whereby a and $\mathrm{b}$ were the major and minor semi-axes (Hagedorn et al., 1998).

Statistics. The experimental randomized block design (RBD) was used with repeated treatments and six blocks. 
The treatments were arranged in a $4 \times 2 \times 2+1$ factorial structure (substances, concentrations of substances, internal cryoprotectants and control). To evaluate the effect of the incubators a completely randomized design was adopted with two treatments, experimental and funnel type incubators, with eight replicates.

The results obtained for percentage viable larvae were subjected to nonparametric statistical analysis by the computer package SAS (1999) and, in the case of significant effect, the Kruskal-Wallis test was applied at 5\% significance level. ANOVA was conducted for the variables temperature, oxygen and fertilization rate in the incubators and, in the case of significant effect, the means were subjected to the Scott-Knott test. ANOVA was also conducted for morphometric analysis and, in the case of significant effect, the means were subjected to the Dunnett test.

\section{Results}

The rate of fertilization did not differ between the incubators $(p>0.05)$. Temperature in the funnel-type incubators was higher $(\mathrm{p}<0.05)$ than in experimental incubators and dissolved oxygen in the funnel-type incubators was higher $(p<0.05)$ than in the experimental incubators during the time of evaluation (Table 1).

Table 1. Average temperature $\left({ }^{\circ} \mathrm{C}\right)$, average oxygen $(\mathrm{mg} / \mathrm{L})$, average fertilization rate (\%) and standard deviation in the experimental and funnel type incubators used in the experiment with Prochilodus lineatus embryos $(\mathrm{n}=6)$. ${ }^{a}$ Averages followed by different letters in the line differ, according to the Scott-Knott test $(\mathrm{p}<0.05)$.

\begin{tabular}{|c|c|c|c|c|}
\hline \multirow{2}{*}{$\begin{array}{c}\text { Time } \\
\text { (Hours) }\end{array}$} & \multicolumn{2}{|c|}{ Temperature $(C)^{\mathrm{a}}$} & \multicolumn{2}{|c|}{ Oxygen $(\mathrm{mg} / \mathrm{L})^{\mathrm{a}}$} \\
\hline & $\begin{array}{c}\text { Funnel } \\
\text { type }\end{array}$ & Experimental & $\begin{array}{c}\text { Funnel } \\
\text { type }\end{array}$ & Experimental \\
\hline $5: 30$ & $25.2 \pm 0.7 \mathrm{a}$ & $22.6 \pm 2.6 b$ & $7.8 \pm 0.5 \mathrm{a}$ & $7.1 \pm 0.1 b$ \\
\hline $6: 30$ & $24.7 \pm 1.1 \mathrm{a}$ & $23.3 \pm 2.1 b$ & $8.3 \pm 0.8 \mathrm{a}$ & $7.5 \pm 0.2 b$ \\
\hline $7: 30$ & $25.3 \pm 0.7 \mathrm{a}$ & $21.7 \pm 3.2 b$ & $10.7 \pm 2.5 \mathrm{a}$ & $8.8 \pm 1.1 \mathrm{~b}$ \\
\hline $8: 30$ & $25.2 \pm 0.8 \mathrm{a}$ & $23.3 \pm 2.1 \mathrm{~b}$ & $8.4 \pm 0.9 \mathrm{a}$ & $7.3 \pm 0.1 b$ \\
\hline $9: 30$ & $26.3 \pm 0.0 \mathrm{a}$ & $24.7 \pm 1.1 b$ & $8.1 \pm 0.7 \mathrm{a}$ & $7.3 \pm 0.1 \mathrm{~b}$ \\
\hline $10: 30$ & $26.5 \pm 0.1 \mathrm{a}$ & $25.5 \pm 0.6 \mathrm{~b}$ & $7.7 \pm 0.4 \mathrm{a}$ & $6.2 \pm 0.6 b$ \\
\hline $12: 30$ & $27.3 \pm 0.6 \mathrm{a}$ & $25.8 \pm 0.4 b$ & $8.8 \pm 1.1 \mathrm{a}$ & $6.2 \pm 0.6 \mathrm{~b}$ \\
\hline $13: 30$ & $26.2 \pm 0.0 \mathrm{a}$ & $26.0 \pm 0.2 b$ & $8.1 \pm 0.6 \mathrm{a}$ & $6.7 \pm 0.2 b$ \\
\hline $14: 30$ & $27.3 \pm 0.6 \mathrm{a}$ & $26.4 \pm 0.1 b$ & $8.1 \pm 0.7 \mathrm{a}$ & $6.2 \pm 0.6 b$ \\
\hline $15: 30$ & $27.3 \pm 0.6 \mathrm{a}$ & $26.6 \pm 0.1 b$ & $8.0 \pm 0.6 \mathrm{a}$ & $6.4 \pm 0.5 b$ \\
\hline \multicolumn{5}{|c|}{ Fertilization rate $(\%) \mathrm{NS}$} \\
\hline \multicolumn{3}{|c|}{ Funnel type } & \multicolumn{2}{|c|}{ Experimental } \\
\hline \multicolumn{3}{|c|}{$88.1 \pm 15.8$} & \multicolumn{2}{|c|}{$79.6 \pm 13.2$} \\
\hline
\end{tabular}

The treatments consisting of $3 \%$ DMSO combined with 0.5 and $1.0 \%$ PVA, $0.5 \%$ GEL and $1.0 \%$ HEC had a higher percentage $(p<0.05)$ of viable larvae in relation to the use of EG for the same combinations, but the HEC $1.0 \%$ was better when combined with $3 \%$ DMSO. It was observed that during the embryos exposure to HEC they were dehydrated without breaking the membrane. The use of DMSO combined with HEC $1.0 \%$ showed similar results $(p>0.05)$ for the percentage of viable larvae compared with the control. On the other hand, it was observed that the other treatments were lower $(\mathrm{p}<0.05)$ than for the control group.

When DMSO was used as internal cryoprotectant, the highest $(p<0.05)$ percentage of viable larvae were obtained with combinations of $1.0 \%$ HEC compared with the combinations of $0.5 \%$ HEC, $1.0 \%$ gelatin, BSF $4 \%$ and $8 \%$ and $0.5 \%$ PVA. No differences were observed between the other treatments. With EG, the combination with $1.0 \%$ gelatin presented a higher $(\mathrm{p}<0.05)$ percentage of viable larvae in relation to BSF $8 \%$ and $0.5 \%$ PVA. However, no significant differences $(\mathrm{p}>0.05)$ were observed between the other treatments (Table 2).

Table 2. Average percentage (\%) and standard deviation of viable larvae of Prochilodus lineatus subjected to different cryoprotectants. ${ }^{a, b}$ Averages followed by different capital letters in the line and small letters in the columns differ, according to the Krustal-Wallis test $(p<0.05)$. PVA: polyvinyl alcohol; GEL: gelatin; HEC: hydroxyethylcellulose; BSF: fetal bovine serum. ${ }^{1}$ Differs from control, according to the Krustal-Wallis test $(\mathrm{p}<0.05)$.

\begin{tabular}{lccc}
\hline \multirow{2}{*}{ Solution } & Dose & \multicolumn{2}{c}{ Internal Cryoprotectant } \\
\cline { 3 - 4 } & & DMSO & Ethylene glycol \\
\hline PVA & $0.5 \%$ & $34.4 \pm 29.0 \mathrm{Abc}$ & $8.4 \pm 18.4 \mathrm{Bbc}$ \\
& $1.0 \%$ & $52.7 \pm 24.0 \mathrm{Aab}$ & $11.2 \pm 13.1 \mathrm{Babc}$ \\
Gelatin & $0.5 \%$ & $54.4 \pm 37.9 \mathrm{Aab}$ & $16.1 \pm 25.2 \mathrm{Babc}$ \\
& $1.0 \%$ & $40.4 \pm 26.4 \mathrm{~b}$ & $39.2 \pm 31.8 \mathrm{a}$ \\
Hydroxyethyl & $0.5 \%$ & $46.3 \pm 38.9 \mathrm{~b}$ & $25.4 \pm 29.5 \mathrm{ab}$ \\
Cellulose & $1.0 \%$ & $72.9 \pm 23.9 \mathrm{Aa}$ & $29.4 \pm 33.7 \mathrm{Bab}$ \\
& $4 \%$ & $16.1 \pm 19.3 \mathrm{c}$ & $13.2 \pm 32.4 \mathrm{abc}$ \\
\hline BSF & & & \\
\hline
\end{tabular}

The medium chorion diameter (CD) subjected to 15 minutes of cryoprotectants decreased $(p<0.05)$ for DMSO PVA $1.0 \%$, EG PVA $1.0 \%$, DMSO PVA $0.5 \%$, EG GEL $1.0 \%$, EG HEC $1 \%$, EG HEC $0.5 \%$, DMSO BSF $8 \%$, EG BSF $8 \%$, DMSO BSF $4 \%$ and EG BSF $4 \%$ compared with 
the control. The $\mathrm{CD}$ subjected to $30 \mathrm{~min}$ of cryoprotectants decreased $(p<0.05)$ compared with the control for DMSO PVA $0.5 \%$, DMSO BSF $8 \%$, EG BSF $8 \%$ and EG BSF $4 \%$ and increased $(p<0.05)$ compared with the control for all other treatments except for EG GEL 1.0\%, DMSO GEL $0.5 \%$, EG GEL $0.5 \%$ and DMSO BSF $4 \%$, which did not present significant difference $(\mathrm{p}>0.05)$. The $\mathrm{CD}$ subjected to $60 \mathrm{~min}$ of cryoprotectants decreased $(\mathrm{p}<0.05)$ compared with the control for DMSO PVA $1.0 \%$, EG PVA $1.0 \%$, DMSO PVA $0.5 \%$, EG BSF $8 \%$, DMSO BSF $4 \%$ and EG BSF $4 \%$ and increased $(\mathrm{p}<0.05)$ compared with the control for all other treatments except for EG GEL 1.0\% and DMSO BSF $8 \%$, which did not present significant difference $(\mathrm{p}>0.05)$ compared with the control (Table 3$)$.

Table 3. Average chorion diameter $(\mathrm{CD})(\mu \mathrm{m})$ and standard deviation of Prochilodus lineatus embryos subjected to different cryoprotectants for different duration (up to $60 \mathrm{~min})$. DMSO: dimethylsulfoxide; EG: ethylene glycol; PVA: polyvinyl alcohol; GEL: gelatin; HEC: hydroxyethylcellulose; BSF: fetal bovine serum; 8: 8\%; 4 : $4 \%$. ${ }^{a *}$ Differs from control, according to the Dunnett test $(\mathrm{p}<0.05) ; \mathrm{CV}=$ coefficient of variation.

\begin{tabular}{|c|c|c|c|}
\hline Treatment & $15 \mathrm{~min}$ & $30 \mathrm{~min}$ & $60 \mathrm{~min}$ \\
\hline WATER & $4031.30 \pm 37.01$ & $2078.00 \pm 61.50$ & $3555.30 \pm 101.10$ \\
\hline DMSO PVA $1.0 \%$ & $3057.30 \pm 37.44 *$ & $3022.66 \pm 58.50 *$ & $3039.00 \pm 63.37^{*}$ \\
\hline EG PVA $1.0 \%$ & $3058.00 \pm 48.49^{*}$ & $3346.00 \pm 21.00 *$ & $3134.70 \pm 10.06^{*}$ \\
\hline DMSO PVA $0.5 \%$ & $3306.00 \pm 96.06^{*}$ & $1651.66 \pm 29.02 *$ & $3117.70 \pm 21.59^{*}$ \\
\hline EG PVA $0.5 \%$ & $4118,70 \pm 72,14$ & $2295,33 \pm 72,14 *$ & $4094,70 \pm 39,20 *$ \\
\hline DMSO GEL $1.0 \%$ & $3913.30 \pm 48,08$ & $2363.66 \pm 59.24 *$ & $3963.70 \pm 85.00^{*}$ \\
\hline EG GEL $1.0 \%$ & $3590.70 \pm 42.50 *$ & $2137.33 \pm 24.68$ & $3510.30 \pm 44.41$ \\
\hline DMSO GEL $0.5 \%$ & $4020.70 \pm 101.00$ & $2127.33 \pm 72.23$ & $3623.00 \pm 45.39^{*}$ \\
\hline EG GEL $0.5 \%$ & $4041.30 \pm 69.00$ & $2095.33 \pm 156.01$ & $3775.00 \pm 110.72 *$ \\
\hline DMSO HEC $1.0 \%$ & $4107.30 \pm 48.05$ & $2206.66 \pm 69.06^{*}$ & $3766.00 \pm 101.37^{*}$ \\
\hline EG HEC $1.0 \%$ & $3708.30 \pm 95.51 *$ & $2271.33 \pm 48.34 *$ & $3684.30 \pm 17.95^{*}$ \\
\hline DMSO HEC $0.5 \%$ & $3934.70 \pm 53.37$ & $2229.33 \pm 8.32 *$ & $3751.30 \pm 51.01^{*}$ \\
\hline EG HEC $0.5 \%$ & $3809.00 \pm 164.50^{*}$ & $2375.33 \pm 164.50 *$ & $4074.70 \pm 13.79^{*}$ \\
\hline DMSO BSF $8 \%$ & $3568.00 \pm 265.51^{*}$ & $1947.33 \pm 67.68^{*}$ & $3523.00 \pm 49.66$ \\
\hline EG BSF $8 \%$ & $3621.70 \pm 95.51^{*}$ & $1927.33 \pm 60.04 *$ & $3413.70 \pm 153.95^{*}$ \\
\hline DMSO BSF $4 \%$ & $3712.00 \pm 16.09^{*}$ & $2066.33 \pm 21.03$ & $3406.30 \pm 160.12^{*}$ \\
\hline EG BSF $4 \%$ & $3724.00 \pm 47.50 *$ & $1953.33 \pm 13.31^{*}$ & $3400.00 \pm 54.36^{*}$ \\
\hline CV (\%) & 2.76 & 2.70 & 2.23 \\
\hline
\end{tabular}

The average embryo diameter (ED) subjected to $15 \mathrm{~min}$ of cryoprotectants increased $(\mathrm{p}<0.05)$ compared with the control for all treatments except for DMSO PVA 1.0\%, EG PVA 1.0\%, DMSO PVA $0.5 \%$, EG GEL $1.0 \%$, EG HEC $0.5 \%$, EG BSF
$4 \%$. The ED subjected to 30 min of cryoprotectants increased $(\mathrm{p}<0.05)$ compared with the control for DMSO PVA $1.0 \%$, EG PVA $1.0 \%$, DMSO GEL $1 \%$ and DMSO HEC $0.5 \%$. The embryo diameter (ED) subjected to 60 min of cryoprotectants decreased $(p<0.05)$ compared with the control for DMSO PVA $0.5 \%$, EG PVA $0.5 \%$, DMSO GEL $1.0 \%$, EG GEL $1.0 \%$, EG HEC $0.5 \%$, EG HEC $1.0 \%$, DMSO BSF $8 \%$, DMSO BSF $4 \%$ and EG BSF $4 \%$ and increased $(p<0.05)$ compared with the control for EG BSF $8 \%$ (Table 4).

Table 4. Average embryo diameter (ED) $(\mu \mathrm{m})$ and standard deviation of Prochilodus lineatus embryos subjected to different cryoprotectants for different duration (up to $60 \mathrm{~min}$. DMSO: dimethylsulfoxide; EG: ethylene glycol; PVA: polyvinyl alcohol; GEL: gelatin; HEC: hydroxyethylcellulose; BSF: fetal bovine serum. ${ }^{a}$ Differs from control, according to the Dunnett test $(\mathrm{p}<0.05)$; CV $=$ coefficient of variation.

\begin{tabular}{cccc}
\hline \multicolumn{1}{c}{ Treatment } & $15 \mathrm{~min}$ & $30 \mathrm{~min}$ & $60 \mathrm{~min}$ \\
\hline WATER & $1186.00 \pm 37.98$ & $694.33 \pm 7.93$ & $1381.70 \pm 29.02$ \\
\hline DMSO PVA $1.0 \%$ & $1218.00 \pm 22.60$ & $1163.00 \pm 35.11^{*}$ & $1348.70 \pm 31.34$ \\
EG PVA 1.0\% & $1215.00 \pm 29.73$ & $1153.33 \pm 15.30^{*}$ & $1308.30 \pm 25.50$ \\
DMSO PVA 0.5\% & $1176.70 \pm 5.56$ & $669.66 \pm 11.50$ & $1230.30 \pm 76.03 *$ \\
EG PVA 0.5\% & $1284.00 \pm 37,87^{*}$ & $724.66 \pm 5.50$ & $1197.30 \pm 68.79^{*}$ \\
DMSO GEL 1.0\% & $1329.30 \pm 18.08^{*}$ & $759.66 \pm 28.51^{*}$ & $1232.70 \pm 32.41^{*}$ \\
EG GEL 1.0\% & $1194.00 \pm 25.57$ & $692.00 \pm 61.58$ & $1156.00 \pm 100.80^{*}$ \\
DMSO GEL 0.5\% & $1267.70 \pm 11.59^{*}$ & $693.67 \pm 29.02$ & $1365.30 \pm 174.13$ \\
EG GEL 0.5\% & $1285.70 \pm 51.59^{*}$ & $701.66 \pm 34.00$ & $1361.00 \pm 97.68$ \\
DMSO HEC 1.0\% & $1248.70 \pm 9.86^{*}$ & $709.33 \pm 61.13$ & $1320.00 \pm 5.68$ \\
EG HEC 1.0\% & $1238.70 \pm 7.76^{*}$ & $685.33 \pm 36.29$ & $1047.30 \pm 35.57 *$ \\
DMSO HEC 0.5\% & $1283.70 \pm 22.74 *$ & $819.33 \pm 3.51^{*}$ & $1311.70 \pm 53.50$ \\
EG HEC 0.5\% & $1169.70 \pm 37.00$ & $698.33 \pm 44.50$ & $1201.00 \pm 158.52^{*}$ \\
DMSO BSF 8\% & $1242.00 \pm 67.06^{*}$ & $673.00 \pm 52.31$ & $1263.00 \pm 59.13 *$ \\
EG BSF 8\% & $1253.70 \pm 15.37 *$ & $653.33 \pm 9.07$ & $1524.70 \pm 65.04 *$ \\
DMSO BSF 4\% & $1244.30 \pm 66.02^{*}$ & $669.66 \pm 18.02$ & $1252.70 \pm 77.13^{*}$ \\
EG BSF 4\% & $1172.00 \pm 38.43$ & $674.00 \pm 23.45$ & $1175.30 \pm 63.51^{*}$ \\
\hline CV $(\%)$ & 2.93 & 4.40 & 6.34 \\
\hline
\end{tabular}

The medium volume after 15 min of cryoprotectants was different $(\mathrm{p}<0.05)$ from that of the control for all treatments except for EG GEL 1.0\%, DMSO GEL $0.5 \%$ and EG GEL $0.5 \%$. The medium volume after $30 \mathrm{~min}$ of cryoprotectants was different $(p<0.05)$ from that of the control for all treatments except for EG GEL $0.5 \%$. The medium volume after 60 min of cryoprotectants was different $(p<0.05)$ from that of the control for all treatments except for EG GEL $1.0 \%$, DMSO GEL $0.5 \%$ and DMSO BSF $8 \%$ (Table 5). 
Table 5. Average volume embryo $\left(\mathrm{mm}^{3}\right)$ and standard deviation of Prochilodus lineatus embryos subjected to different cryoprotectants for different duration (up to $60 \mathrm{~min})$. DMSO: dimethylsulfoxide; EG: ethylene glycol; PVA: polyvinyl alcohol; GEL: gelatin; HEC: hydroxyethylcellulose; BSF: fetal bovine serum. ${ }^{*}$ Differs from control, according to the Dunnett test $(\mathrm{p}<0.05)$; $\mathrm{CV}=$ coefficient of variation.

\begin{tabular}{|c|c|c|c|}
\hline Treatment & $15 \mathrm{~min}$ & $30 \mathrm{~min}$ & $60 \mathrm{~min}$ \\
\hline WATER & $1122.35 \pm 6.45$ & $82 \pm 69.82$ & $644.85 \pm 95.70$ \\
\hline DMSO PVA 1.0\% & $349.6 \pm 14.99 *$ & $354.9 \pm 29.60^{*}$ & $322.1 \pm 24.08^{*}$ \\
\hline EG PVA $1.0 \%$ & $355.51 \pm 16.51^{*}$ & $535.89 \pm 22.55^{*}$ & $350.31 \pm 8.38^{*}$ \\
\hline DMSO PVA $0.5 \%$ & $465.16 \pm 2.76^{*}$ & $30.60 \pm 48.45^{*}$ & $351.31 \pm 48.19^{*}$ \\
\hline EG PVA $0.5 \%$ & $1104.32 \pm 9.47^{*}$ & $100.72 \pm 30.08^{*}$ & $1112.33 \pm 70.93 *$ \\
\hline DMSO GEL $1.0 \%$ & $1008.61 \pm 10.28^{*}$ & $119.31 \pm 78.73^{*}$ & $974.78 \pm 102.10^{*}$ \\
\hline EG GEL 1.0\% & $793.54 \pm 4.63 *$ & $86.56 \pm 23.20$ & $618.18 \pm 42.99$ \\
\hline DMSO GEL $0.5 \%$ & $1092.90 \pm 11.79^{*}$ & $93.13 \pm 7.27$ & $691.50 \pm 28.93$ \\
\hline EG GEL $0.5 \%$ & $1183.48 \pm 25.06$ & $87.51 \pm 2.48$ & $815.84 \pm 114.40^{*}$ \\
\hline DMSO HEC $1.0 \%$ & $1077.32 \pm 42.52 *$ & $108.31 \pm 10.96^{*}$ & $807.80 \pm 95.17 *$ \\
\hline EG HEC $1.0 \%$ & $771.87 \pm 57.66^{*}$ & $109.16 \pm 5.56^{*}$ & $741.96 \pm 40.07 *$ \\
\hline DMSO HEC $0.5 \%$ & $926.41 \pm 35.50 *$ & $108.57 \pm 8.07^{*}$ & $814.09 \pm 35.50 *$ \\
\hline EG HID $0.5 \%$ & $846.63 \pm 137.54 *$ & $118.70 \pm 2.87^{*}$ & $1029.91 \pm 24.94 *$ \\
\hline DMSO BSF $8 \%$ & $641.65 \pm 164.61^{*}$ & $62.35 \pm 10.56^{*}$ & $633.16 \pm 16.71$ \\
\hline EG BSF $8 \%$ & $645.39 \pm 91.97 *$ & $54.20 \pm 8.14 *$ & $507.68 \pm 109.31 *$ \\
\hline DMSO BSF 4\% & $832.34 \pm 53.27^{*}$ & $70.65 \pm 5.05^{*}$ & $544.20 \pm 90.64 *$ \\
\hline EG BSF $4 \%$ & $802.30 \pm 41.38^{*}$ & $65.74 \pm 0.76^{*}$ & $521.39 \pm 10.10^{*}$ \\
\hline CV (\%) & 9.70 & 8.40 & 9.90 \\
\hline
\end{tabular}

\section{Discussion}

Fertilization success is probably one of the earliest estimators that can be used for accurately estimation of egg quality and it is the most integrative estimator of sperm quality. Indeed, the ability to fertilize or be fertilized is one of the key components of gamete quality. Recording of fertilization rates is relatively easy in some species, thanks to the transparency of their eggs (Bobe \& Labbé, 2010). Our results show high fertilization rates in both incubator types and can be considered satisfactory in a system of artificial reproduction, as in the case of funnel-type incubators, and an experimental system, as in the case of experimental incubators. The experimental incubators are advantageous because they allow normal development of embryos in solutions with fixed concentrations and require little space.

The fact that temperature in the funnel-type incubators was higher than in experimental incubators may be attributed to the conditions in which the funnel-type incubators are used, as they receive water from a tank with a heating system and constant renewal, which keeps the temperature constant. However, the experimental incubators had no exchange of water or heating system and were controlled by room temperature. The lower temperature oscillation leads to a lower frequency of heat shocks, which can help the overall performance of the incubation of eggs and larvae (Johnston \& Vieira, 1996).

The time difference for embryonic development may be directly related to incubation temperature (Saka et al., 2004). This was observed for curimba embryos in average temperatures of $24^{\circ} \mathrm{C}$ and $28^{\circ} \mathrm{C}$, where hatching occurred 22 and $14 \mathrm{~h}$ after fertilization, respectively (Ninhaus et al., 2006). As the temperatures were very close to the comfort range, our larvae took less time to hatch, but the incubation maintained the viability of the larvae, which was observed in satisfactory development rates.

According to Rodrigues-Galdino et al., (2009) water temperature is a major determining factor in fish development. It is always advisable to use the optimal temperature for the species. Studies show that acceptable temperature for the incubation of eggs of tropical fish varies from $22^{\circ} \mathrm{C}$ to $31^{\circ} \mathrm{C}$, and the best temperature is $27^{\circ} \mathrm{C}$ (Johnston \& Vieira, 1996). All temperatures in both incubators were around this comfort range for most of the evaluated period.

The dissolved oxygen in the funnel-type incubators was higher than in the experimental incubators during the time of evaluation, justified by the conditions in which the funnel-type incubators are used, as they have constant water renewal and oxygenation. However, this difference in oxygen concentration did not affect embryo viability. Studies show that oxygen consumption by the eggs is very low in the early stages of development, and accelerates gradually (Strecker et al., 2011). The oxygen demand of the developing embryo increases dramatically with temperature, i.e., dissolved oxygen should not be separated from other factors synchronous with temperature, $\mathrm{pH}$, and altitude, among others (Barroso \& Santos, 2006).

The DMSO is a widely used cryoprotectant during the cooling processes, both for the cryopreservation/ vitrification of semen and embryos and this cryoprotectant has as advantage the rapid permeation into the membrane (Hagedorn et al., 1997a, b, 1998; Zhang \& Rawson 1996). In our study the DMSO showed lower toxicity during incubation of the embryo for longer periods compared with ethylene glycol, being the cryoprotectant suggested for these conditions. However, the concentration and the cryoprotectant entering the yolk/YSL region should be widely studied. Ultra structural experiments by Hagedorn et al., (1998) suggested that cryodamage led to the death of the embryos in part because of insufficient cryoprotectant entering the yolk/YSL region.

The fact that the internal cryoprotectant 3\% EG showed a lower percentage of viable larvae in relation to 
the 3\% DMSO, combined with 0.5 and $1.0 \%$ PVA, $1.0 \%$ HEC and $0.5 \%$ GEL, can be related to the detrimental effect of the cryoprotectant, because it may interfere with the metabolism of the embryo to cause cell disruption and consequently death (Streit Jr et al., 2007). These results are in agreement with those obtained by Hagedorn et al., (1997b), who observed that the exposure of threesomite embryos to $1.5 \mathrm{M}$ glycerol or ethylene glycol was deleterious for zebrafish, whereas ethylene glycol caused the blastoderm to dissociate from the yolk within 60 minutes.

The fact that HEC determines higher rates of embryo viability shows that this polymer could be a future means of cryopreservation, mainly because it has the viscosity of the various products that are used and a low freezing temperature, according to the manufacturer. From the results of the present work, we can assume that this substance was less toxic to the embryos. Our work is probably the first to describe the use of this substance during the embryonic development in this species. The HEC is a natural polysaccharide with chemical modifications and the beneficial effect of this compound is probably owed to its properties of non-toxicity, biocompatibility and biodegradability (Peng \& Chen, 2010). Dehydration was observed for the embryos of EG HEC $1.0 \%$ and EG HEC $0.5 \%$ and did not observe to other treatments during the first $15 \mathrm{~min}$, which may be because of the action of internal cryoprotectants, and after this period, the embryos were hydrated in all treatments after 30 and $60 \mathrm{~min}$ of exposure. However, hydration can be a barrier to cryopreservation whereas dehydration is expected to prevent formation of intracellular ice.

On the other hand, the ED of the embryos exposed to certain combinations of HEC increased during the first 15 min. Similar results were observed by Lahnsteiner (2008) for zebrafish in that the diameter of the yolk increased after 5 min exposure to DMSO and sucrose solutions. Lahnsteiner concluded that this process was coupled with the shrinkage of the perivitelline space and speculated that during shrinkage the egg lost its tension, enabling the yolk to expand, and during further incubation the further increase in the width of the perivitelline space and in the egg tension could have led to recompression of the yolk.

Although the PVA did not show satisfactory results compared with other treatments, this substance may play an important role as an external cryoprotectant, mainly because of its degradability and non-toxic properties (Batyrbekov et al., 1998). The use of cryogels has shown increased viability in smooth muscle cells, when combined with DMSO (Vrana et al., 2011), and there are studies that prove the reduction in ice crystal formation, derived from freezing (Holt, 2003). Our results also show the beneficial effects of these cryoprotectants for freezing, explained by $\mathrm{CD}$ and combinations of cryoprotectants internal PVA induced loss of water in the embryo at $15 \mathrm{~min}$ (except
EG PVA 0.5\%), and this behaviour continued throughout the 30 and 60 min exposure, including the EG PVA $0.5 \%$ treatment. Evaluating the ED some of the embryos exposed to combinations of PVA, increased at 15 and $30 \mathrm{~min}$ and only two treatments led to dehydration at $60 \mathrm{~min}$ (DMSO PVA $0.5 \%$ and EG PVA $0.5 \%$ ). PVA is a biomaterial with potential for biomedical applications and the design of new nanostructured devices; it is water soluble, biocompatible and has physical properties (Paradossi et al., 2003) such as a rubbery nature and a high degree of swelling in water (Nikolaos \& Stauffer, 1991)

Gelatin associated with EG resulted in higher rates of viable larvae compared with $8 \% \mathrm{BSF}$. Gelatin is a composite of essential and non-essential amino acids that may have contributed to the nutrition of the embryos without being highly toxic. Furthermore, gelatin is used as a delivery vehicle for the controlled release of bioactive molecules (Young et al., 2005) and used for pharmaceutical and medical applicatons because of its biodegrability (Tabata \& Ikada, 1998).

The results for $\mathrm{CD}$ and $\mathrm{ED}$ with gelatin were very variable, but we observed compensation between two measures. Similar results were observed in zebrafish by Lahnsteiner (2008) in that the further increase in the width of the perivitelline space and in the egg tension could have led to recompression of the yolk. BSF is a compound of bovine blood proteins and may have been toxic to curimba embryos, which has not been observed for bovine embryos as it accounts for an increase in their growth (Lonergan et al., 1999).

Zhang \& Rawson (1996) measured the volume in the outer chorion to determine the cryoprotectant permeation of intact six-somite and $27 \mathrm{~h}$ embryos. Importantly, after 30 minutes of exposure, all embryos shrank, except those which received EG GEL $0.5 \%$ treatment in our study. Hagerdorn et al., (1998) also observed for zebrafish that embryos shrank over time and did not re-expand while immersed in DMSO or propylene glycol for long periods (i.e., $60 \mathrm{~min}$ ). Our results show that in the presence of DMSO or EG there is membrane water permeability and this is important to measure, in addition the exposure time, mainly in future protocols for cryopreservation. According to Hagedorn et al., (1997a, b) the efficacy of cryoprotectant permeation and equilibration is crucial for successful cryopreservation procedures.

BSF in association with EG may have caused a change in the homeostasis of embryos, and some authors report a low potential for detoxification of regulatory pathways in early ontogenetic stages since in these phases the embryos are still undeveloped and unable to compensate for the toxic effect of cryoprotectants (Lahnsteiner, 2008). It was observed during this study that use of $4 \%$ and $8 \%$ fetal bovine serum led to severe dehydration of the embryos, which we believe was deleterious.

BSA and FCS (fetal calf serum or BSF) are commonly used in freezing solutions at $4 \mathrm{mg} / \mathrm{mL}$ or $10 \%$ respectively 
in bovine embryos, and according to Gordon (1994) are widely used in the freezing medium as extracellular cryoprotectants. The study by Pugh et al., (1998) compared the addition of fetal bovine serum and fetal serum albumin (BSA) in a culture medium of bovine embryos and observed that the survival of late morulae/early blastocysts following freezing was improved in the presence of additional BSA but not BSF in vitro. Dehydration of the embryo before freezing would be an interesting approach in the cryopreservation process, thereby avoiding the formation of intracellular ice.

Our results for $\mathrm{CD}$ and $\mathrm{ED}$ show that BSF matched with internal cryoprotectants dehydrates the embryos during the majority of the exposure time and forces the water out of the embryo and consequently its dehydration. Thus, the use of fetal bovine serum with internal cryoprotectants before freeze drying may cause this result but during a short exposure because for $8 \mathrm{~h}$ the damage curimba embryos had low survival rates.

The unsuccessful cryopreservation of fish embryos may be related to the lower permeability of the embryonic membranes (Hagedorn et al., 1997b). Thus, embryos exposed to low concentrations of internal cryoprotectant (3\% would be least toxic), throughout the period of embryonic development from fertilization to $8 \mathrm{~h}$ approximately, when blastopore closure occurs (Botta et al., 2010), might allow for greater input of cryoprotectant in all embryonic compartments.

The combinations of tested cryoprotectants maintained the viability of curimba embryos except for the combination of ethylene glycol and $8 \%$ BSF. The use of combined DMSO and $1.0 \%$ HEC is suggested as a potential solution for embryo cryopreservation since toxicity is lower. It should also be noted the permeation of cryoprotectants in embryos through the changes in chorion diameter, embryo diameter and embryo volume, this results can help in future cryopreservation protocols. The use of a reduced model of experimental incubators is an alternative for studying the toxic effect of cryopreservation solutions on embryo development for long periods and for maintaining embryos viability.

\section{Acknowledgements}

Thanks to Fundação de Amparo à Pesquisa do Estado de Minas Gerais (Foundation for Research Support of Minas Gerais), Capes and CNPq for financial support, to Estação Ambiental de Itutinga da Companhia Energética de Minas Gerais (Itutinga Environmental Station of the Companhia Energética de Minas Gerais) (EAI-CEMIG) for support with the development of this work, and Programa de Pós-Graduação em Zootecnia da Universidade Federal de Lavras (Graduate Programme in Animal Science of the Universidade Federal de Lavras) for both assistance with the research and financial support.

\section{Literature Cited}

Barroso, H. G. \& A. J. G. Santos. 2006. Incubadora HB para ovos de peixes de água doce e sua larvicultura (PATENTE: MU 7903279-6*). Revista Brasileira de Engenharia de Pesca, 1: 119-143.

Batyrbekov, E. O., R. Iskakov \& B. A. Zhubanov. 1998. Synthetic and natural polymers as drug carriers for tuberculosis treatment. Macromolecular Symposia, 127: 251-256.

Bobe, J. \& C. Labbé. Egg and sperm quality in fish. 2010. General and Comparative Endocrinology, 165: 535-548.

Botta, P., A. Sciara, S. Arranz, L. D. S. Murgas, G. J. M. Pereira \& G. Oberlender. 2010. Estudio del desarrollo embrionario del sábalo (Prochilodus lineatus). Archivos de Medicina Veterinaria, 42: 109-114.

Checura, C. M. \& G. E. Seidel Jr. 2007. Effect of macromolecules in solutions for vitrification of mature bovine oocytes. Theriogenology, 67: 919-930.

Di Prinzio, C. M., P. E. Botta, E. H. Barriga, E. A. Ríos, A. E. Reyes \& S. E. Arranz. 2010. Growth hormone receptors in zebrafish (Danio rerio): adult and embryonic expression patterns. Gene Expression Patterns, 10: 214-225.

Felizardo, V. O., L. D. S. Murgas, M. M. Drumond \& J. A. Silva. 2010. Dose inseminante utilizada na fertilização artificial de ovócito de piracanjuba (Brycon orbignyanus). Revista Ceres, 57: 648-652.

Fornari, D. C, R. P. Ribeiro, D. P. Streit Jr, L. Vargas, N. M. L. Barrero \& G. V. Moraes. 2011. Freezing injuries in the embryos of Piaractus mesopotamicus. Zygote, 19: 345350 .

Gordon, I. 1994. Laboratory Production of Cattle Embryos. CAB International. $\mathrm{n}^{\circ} 11$. Cambridge, UK: Cambridge University Press, 1994. 640p.

Haffter, P., M. Granato, M. Brand, M. C. Mullins, M. Hammerschmidt, D. A. Kane, J. Odenthal, F. J. M. Van Eeden, Y. Jiang, C. Heisenberg, R. N. Kelsh, M. FurutaniSeiki, E. Vogelsang, D. Beuchle, U. Schach, C. Fabian \& C. Nüsslein-Volhard. 1996. The identification of genes with unique and essential functions in the development of the zebrafish, Danio rerio. Development, 123: 1-36.

Hagedorn, M., E. Hsu, F. W. Kleinhans \& D. E. Wildt. 1997a. New approaches for studying the permeability of fish embryos: Toward successful cryopreservation. Cryobiology, 34: 335-347.

Hagedorn M., E. Hsu, U. Pilatus, D. E. Wildt, W. F. Rall \& S. J. Blackband. 1996. Magnetic resonance microscopy and spectroscopy reveal kinetics of cryoprotectant permeation in a multicompartmental biological system. Proceedings of the National Academy of Sciences of the United States of America, 93: 7454-7459.

Hagedorn, M., E. W. Kleinhans, D. E. Wildt, \& W. E. Rall. 1997b. Chilling sensitivity and cryoprotectant permeability of dechorionated zebra fish embryos, Brachidanio rerio. Cryobiology, 34: 251-63.

Hagedorn, M., F. W. Kleinhans, D. Artemov \& U. Pilatus. 1998. Characterization of a major permeability barrier in the zebrafish embryo. Biology of Reproduction, 59: 12401250 .

Holt, C. B. 2003. The effect of antifreeze proteins and polyvinyl alcohol) on the nucleation of ice: A preliminary study. Cryo Letters, 24: 323-330. 
Johnston, I. A. \& V. L. A. Vieira. 1996. Larval development in the tambaqui (Colossoma macropomum) and the curimatãpacú (Prochilodus marggravii). Pp. 43-55. In: Vahl, O. \& D. J. Randall (eds.). The Physiology \& Biochemistry of Amazonian Fishes. Manaus, INPA Press.

Kusuda, S., T. Teranishi \& N. Koide. 2002. Cryopreservation of chum salmon blastomeres by the straw method. Cryobiology, 45: 60-67.

Lahnsteiner, F. 2008. The effect of internal and external cryoprotectants on zebrafish (Danio rerio) embryos. Theriogenology, 69: 384-396.

Lonergan, P., M. O'Kearney-Flynna \& M. P. Bolanda. 1999. Effect of protein supplementation and presence of antioxidant on the development of bovine zygotes in syntetic oviduct fluid medium under high or low oxygen tension. Theriogenology, 51: $1565-1576$.

Lopes, T. S., E. Romagosa, D. P. Streit Jr, R. P. Ribeiro \& M. Digmayer. 2011. Cooling of pacu (Piaractus mesopotamicus) embryos at various stages of development for 6 or 10 hours. Theriogenology, 75: 570-576.

Maduenho, L. P. \& C. B. R. Martinez. 2008. Acute effects of diflubenzuron on the freshwater fish Prochilodus lineatus. Comparative Biochemistry and Physiology Part C: Toxicology \& Pharmacology, 148: 265-272.

Martínez-Páramo, S., V. Barbosa, S. Pérez-Cerezales, V. Robles \& M.P. Herráez. 2009. Cryoprotective effects of antifreeze proteins delivered into zebrafish embryos. Cryobiology, 58: 128-133.

Martínez-Páramo, S., S. Pérez-Cerezales, V. Robles, L. Anel \& M.P. Herráez. 2008. Incorporation of antifreeze proteins into zebrafish embryo by anon-invasive method, Cryobiology, 56 : 216-222.

Murgas, L. D. S., A. B. Miliorini, R. T. F. Freitas \& G. J. M. Pereira. 1997. Criopreservação do sêmen de curimba (Prochilodus lineatus) mediante adição de diferentes diluidores, ativadores e crioprotetores. Revista Brasileira de Zootecnia, 36: 526531.

Naitana, S., S. Ledda, P. Loi, G. Leoni, L. Bogliolo, M. Dattena \& P. Cappai. 1997. Polyvinyl alcohol as a defined substitute for serum in vitrification and warming solutions to cryopreserve ovine embryos at different stages of development. Animal Reproduction Science, 48: 247-256.

Nikolaos A. P. \& S. R. Stauffer. 1991. Reinforced uncrosslinked poly (vinyl alcohol) gels produced by cyclic freezing-thawing processes: a short review. Journal of Controlled Release, 16: 305-310.

Ninhaus-Silveira, A., F. Foresti \& A. Azevedo. 2006. Structural and ultrastructural analysis of embryonic development of Prochilodus lineatus (Valenciennes, 1836) (Characiforme; Prochilodontidae). Zygote, 14: 217-229.

Ninhaus-Silveira, A., F. Foresti, A. Azevedo, C. A. Agostinho \& R. Veríssimo-Silveira. 2009. Cryogenic preservation of embryos of Prochilodus lineatus (Valenciennes, 1836) (Characiforme; Prochilodontidae). Zygote, 17: 45-55.

Nowshari, M. A. \& G. Brem. 2000. The protective action of polyvinyl alcohol during rapid-freezing of mouse embryos. Theriogenology, 53: 1157-1166.

Paradossi, G., F. Cavalieri \& E. Chiessi. 2003. Poly (vinyl alcohol) as versatile biomaterial for potential biomedical application. Journal of Materials Science: Material in Medicine, 14: 687691.
Paula, D. A. J., E. S. Andrade, L. D. S. Murgas, V. O. Felizardo, E. U. Winkaler, W. Zeviani \& R. T. F. Freitas. 2012. Vitamin E and reduced glutathione in Prochilodus lineatus (curimba) semen cryopreservation (Characiformes: Prochilodontidae). Neotropical Ichthyology, 10: 661-665.

Peng, Z. \& F. Chen. 2010. Synthesis and properties of temperature-sensitive hydrogel based on hydroxyethyl cellulose. International Journal of Polymeric Materials 59: 450-461.

Pugh, P. A., A. E. L. Ankersmit, L. T. McGowan \& H.R. Tervit. 1998. Cryopreservation of in vitro-produced bovine embryos: effects of protein type and concentration during freezing or of liposomes during culture on post-thaw survival. Theriogenology, 50: 495-506.

Rodrigues-Galdino, A. M., C. V. Maiolino, M. Forgati, L. Donatti, J. D. Mikos, P. C. F. Carneiro \& F. S. Rios. 2009. Development of the neotropical catfish Rhamdia quelen (Siluriformes: Heptapteridae) incubated in different temperature regimes. Zygote, 18: 131-144.

Saka, Ş., K. Firat \& D. Çoban. 2004. Development of the common dentex (Dentex dentex) eggs in relation to temperature. Aquaculture Research, 35: 224-231.

SAS, 1999. Institute Inc. SAS/STAT Software Release 8.0. Cary, NC: SAS Institute Inc.

Schneider, C. A., W. S. Rasband, K.W. Eliceiri. 2012. "NIH Image to ImageJ: 25 years of image analysis". Nature Methods, 9: 671-675.

Shapiro, Y. E. \& T. I. Shapiro. 1999. 1H NMR Self-diffusion study of PVA cryogels containing ethylene glycol and its oligomers. Journal of Colloid and Interface Science, 217: 322-327.

Strecker, R., T. Seiler, H. Hollert \& T. Braunbeck. 2011. Oxygen requirements of zebrafish (Danio rerio) embryos in embryo toxicity tests with environmental samples. Comparative Biochemistry and Physiology Part C: Toxicology \& Pharmacology, 153: 318-327.

Streit Jr, D. P., M. Digmayer, R. P. Ribeiro, R. N. Sirol, G.V. Moraes \& J. M. Galo. 2007. Embriões de pacu submetidos a diferentes protocolos de resfriamento. Pesquisa Agropecuária Brasileira, 42: 1199-1202.

Tabata, Y. \& Y. Ikada. 1998. Protein release from gelatin matrices. Advanced Drug Delivery Reviews, 31: 287-301.

Vajta, G., N. Rindom, T. T. Peura, P. Holm, T. Greve \& H. Callesen. 1999. The effect of media, serum and temperature on in vitro survival of bovine blastocysts after open pulled straw (ops) vitrification. Theriogenology, 52: 939-948.

Viveiros, A. T. M., Z. A. Isaú, H. C. P. Figueiredo, M. A. S. Leite \& A. N. Maria. 2010a. Gentamycin controls bacterial growth during refrigerated storage of piracanjuba, Brycon orbignyanus, semen. Journal of the World Aquaculture Society, 41: 57-65.

Viveiros, A. T. M., A. F. Nascimento, L. H. Orfão \& Z. A. Isaú. 2010b. Motility and fertility of the subtropical freshwater fish streaked prochilod (Prochilodus lineatus) sperm cryopreserved in powdered coconut water. Theriogenology, 74: 551-556.

Viveiros, A. T. M, L. H. Órfão, A. N. Maria \& I. B Allaman. 2009. A simple, inexpensive and successful freezing method for curimba Prochilodus lineatus (Characiformes) semen. Animal Reproduction Science, 112: 293-300. 
Vrana, N. E., K. Matsumura, S. Hyon, L. M Geever, J. E. Kennedy, J. G. Lyons, C. L. Higginbotham, P. A. Cahill \& G. B. McGuinness. 2011. Cell encapsulation and cryostorage in pva-gelatin cryogels: Incorporation of carboxylated $\varepsilon$-polyL-lysine as cryoprotectant. Journal of Tissue Engineering and Regenerative Medicine, 6: 280-290.

Wowk, B., E. Leitl, C. M. Rasch, N. Mesbah-Karimi, S. B. Harris \& G. M. Fahy. 2000. Vitrification enhancement by synthetic ice blocking agents. Cryobiology, 40: 228-236.

Young S., M. Wong, Y. Tabata \& A. G. Mikos. 2005. Gelatin as a delivery vehicle for the controlled release of bioactive molecules. Journal of Controlled Release, 109: 256-274.
Zhang, T. \& D. M. Rawson. 1996. Feasibility studies on vitrification of intact zebrafish (Brachydanio rerio). Cryobiology, 33: 1-13.

Zhang, T., D. M. Rawson \& J. G. Morris. 1993. Cryopreservation of pre-hatch embryos of zebrafish (Brachydanio rerio). Aquatic Living Resources, 6: 145-53.

Submitted December 25, 2013

Accepted September 13, 2014 by Bernardo Baldisserotto

Published December 27, 2014 